\title{
The St. Louis Hegelians and the Institutionalization of Democratic Education
}

\author{
Joe Ervin \\ University of Nevada, Las Vegas \\ David Beisecker \\ University of Nevada, Las Vegas \\ Jasmin Özel \\ University of Nevada, Las Vegas
}

Although the Hegelian roots of American educational thought, especially that of John Dewey, have recently found more recognition, we argue for a more complete consideration of Hegel's impact on post-Civil War educational thought in the United States. ${ }^{1}$ As James Scott Johnston suggests, "To reread Dewey as significantly Hegelian. . . . demands for a more complete consideration of the role of Hegel in late nineteenth-century American educational thought." " Hegelianism in America after the war exceeded its Prussian source in focusing on the question of how to provide for citizens' freedom in the new democracy, and by arguing that the solution to this question needs to be implemented by means of institutions - in particular, public educational institutions. William Torrey Harris and the St. Louis Hegelians created an educational system for St. Louis that would serve as a model for the whole nation, from kindergarten all the way to the teachers' colleges, and they passed an understanding of Hegel on to Dewey that differed substantially from the neo-theological readings that were widespread in the British academy at the time. By focusing on the commonalities between Harris and Dewey, we also make a preliminary case that Dewey's thought did not constitute as much of a radical break with his Hegelian predecessors, as is commonly claimed. 


\section{WILLIAM TORREY HARRIS AND THE ST. LOUIS}

\section{HEGELIANS}

The American reception of Hegel, especially as it applies to education, owes much to William Torrey-Harris and the St. Louis Hegelians. Yet their fascinating history is still not widely recalled. Originally from Connecticut, Harris moved to St Louis and secured a position teaching in the public schools in 1858 . There, he encountered Henry Brokmeyer, a German émigré who had been compelled by Thoreau's example to move to a secluded cabin outside St. Louis with a mind to "make Hegel speak English" by translating his Greater Logic. It was he who in 1858 introduced — and eventually converted-Harris to Hegelianism. Together, they comprised the intellectual backbone of the St. Louis Philosophical Society, which was formed in 1866. In 1867, this society launched the first academic philosophy journal in the Americas, The Journal of Speculative Philosophy (JSP).

The importance of this journal cannot be overstated. Charles S. Peirce, William James, and Josiah Royce all had early work published in the JSP. Harris published Dewey's first article, "The Metaphysical Assumptions of Materialism," in 1882, while Dewey was still a schoolteacher in Oil City, Pennsylvania. Dewey recounts that Harris encouraged Dewey to pursue graduate studies, which he did, under Harris's friend, George Sylvester Morris, at Johns Hopkins University. Dewey would go on to publish his next three articles for the JSP. ${ }^{3}$ Bankrolled and edited chiefly by Harris, the JSP also brought Hegelian thought to American shores. In addition to translations of Hegel by Henry C. Brokmeyer and Harris, it included several translations of commentaries by his influential biographer, Karl Rosenkranz, who became an auxiliary member of the St. Louis Philosophical Society. ${ }^{4}$ Portraying Hegel as a liberal reformer, Rosenkranz was a "Center" Hegelian, opposed to 
both the conservative "Old" (or right wing) Hegelians and the revolutionary-minded "Young" (or left wing) Hegelians.

Given their attachment to the public schools, it's no great mystery why the St. Louis Hegelians would latch onto Hegel—especially Rosenkranz's understanding of Hegel. Rosenkranz was well-known for working Hegel's thought into an influential philosophy of education. Anna Brackett (Harris's colleague and the first woman to become principal of a normal school) translated sections of his 1848 Die Paedogogik als System for the JSP. ${ }^{5}$ Eventually Harris released an edition of this translation in 1886 under the name of The Philosophy of Education, alongside his own analysis and commentary.

In 1868, Harris became superintendent of the St. Louis Public Schools. Under his leadership, the St. Louis system emerged as an institutional model for the entire nation-encompassing not only primary and secondary schools, but also Brackett's normal school, centers for adult and vocational education, and a library. In 1873, it opened the first public kindergarten in the nation under the direction of another St. Louis Hegelian, Susan Blow. After twelve successful years as superintendent, Harris returned to his Yankee roots and took over the administration of the Concord Summer School of Philosophy from his friend Amos Bronson Alcott. For several years, there had been a steady and fruitful exchange between New England Transcendentalists and St. Louis Hegelians. Emerson and Alcott both lectured at the St. Louis Philosophical Society, and both were auxiliary members. Likewise, Harris, Thomas Davidson, George Howison, and Denton Snider lectured at the Concord School.

The Concord School folded soon after Alcott's death in 1888, and Davidson established a similar school, the Glenmore School, in the Adirondacks in 1889. Harris and Dewey both lectured several 
summers at Glenmore, and both built summer cottages nearby. By this time Harris was recognized as the pre-eminent interpreter of Hegel in America. He finally realized the long-standing aim of the St. Louis Hegelians when he published a translation of Hegel's Logic, in 1890. Dewey drew upon Harris's translation for his lectures on Hegel. However, Harris's renown as an educator and administrator caught up with him, and he was appointed United States Commissioner of Education in 1889, upon the recommendation of Nicholas Murray Butler, president of the National Education Association and founder of the Columbia Teachers College. ${ }^{6}$ There, he served on the famous Committees of Ten and Fifteen, charged with articulating standards for teaching and learning in secondary and elementary education respectively. Harris's hand is evident, especially in the section he wrote on elementary school curriculum in the Report of the Committee of Fifteen (which he chaired). He served for seventeen years as commissioner and died in 1909.

In sum, Dewey's interactions with the St. Louis Hegelians were extensive, formative, and friendly. Moreover, the understanding of Hegel that he would have received from them would have differed dramatically from more conservative, neo-theological interpretations prevalent in the United Kingdom. As Dewey points out, Harris and his fellow St. Louisans were distinctive in reading Hegel through non-liturgical lenses, suggesting further that this is because they were largely working not from within the academy, but in the context of the public schools. Given their religious affiliations, most institutions of higher education at the time (and certainly the most influential institutions) were not the most congenial places for such a secular/humanistic reading of Hegel. Dewey further remarks that Harris's example as a thoroughly professional philosopher working outside of academic confines provided him encouragement that he might find a career through the 
study of philosophy. ${ }^{7}$

\section{THE AMERICAN PARADOX OF DEMOCRATIC EDUCATION IN ST. LOUIS: FROM INDIVIDUALISM TO}

\section{INSTITUTIONALISM}

The St. Louis Hegelians realized that in order to reflect and become attuned to their particular circumstances, American citizens (as opposed to Prussians) would have to reflect democratic values and be prepared to participate in democratic institutions that largely drew boundaries between church and state. This is not to say that America was unfolding a more adequate or complete conception of itself from the perspective of world-history (though Denton Snider certainly thought so). It's simply the recognition that the values of the American populace and its institutions would have to be aligned with one another, and that it was largely up to American educational institutions to bring this alignment about. Among these values were the familiar Emersonian ideals of self-reliance and self-trust—values that might well strike a strict reader of Hegel as alien. However, as we will now see, the early history of educational institutions in America reveals a complex mix of both transcendentalist ideas, such as those surrounding self-determination, and Hegelian ideas, which acknowledge the paradoxical character of educating citizens to participate freely in their new-formed democracy.

Joshua Goldstein has recently argued that Hegel was committed to reconciling two "seemingly contradictory democratic ideals" in education. ${ }^{8}$ The first—an "integrity ideal" exemplified by Plato's Meno-emphasizes that truth lies within, which in turn requires individuals to retreat from the corruptions of public life in order to learn through anamnesis or recollection. The second-a "collectivist ideal" attributed to Rousseau-holds rather that truth can only be found in a 
shared world, suggesting instead that individuals can learn only by immersing themselves in their communities. According to Goldstein, this paradox of integrating the integrity and the collectivist ideals translates into the question of how to provide for citizens' freedom within the state. He finds the resources to reconcile the two sides of the paradox in Hegel's discussion of Bildung in the Philosophy of Right. There, the integrity ideal is described as "spontaneous self-activity," while the collectivist ideal consists of being "at home in the external world." According to Goldstein, the two sides of the paradox are reconciled once the transformative character of Bildung is truly understood: education liberates their recipients from the immediate needs of nature and transforms them from a merely natural being into an ethical one. Education hence makes individuals ethical by removing what's natural and developing their second nature instead, through the "structural and systemic education of individuals through acculturation or cultivation." ${ }^{10}$ In turn, the world spirit overcomes its own immediacy in the course of what Hegel calls history. Once spirit completes this process of self-education, "it reveals both that the integrity ideal (spontaneous self-activity) and the collectivist ideal (to be at home in the external world) are inherent in the historical process itself." 11

We agree that Hegel was concerned about working through tensions within the conception of education, especially in the Philosophy of Right. Eternal truths can only come to life in the individuals who recollect them, and yet the community needs to be acknowledged as the individual's "motivating end and a foundation." 12 However, Goldstein characterizes Hegel's ideas as distinctly democratic, and so takes their reconciliation to be a sufficient warrant to "reclaim Hegel as a theorist of democratic politics." 13 Such a characterization of Hegel as a democratic thinker would come as a surprise to many. 
Instead, we suggest that it was only once Hegelian thought reached St. Louis that the paradox of education takes on democratic overtones. The St. Louis Hegelians saw an "underdeveloped element" and the need to democratize Hegel. ${ }^{14}$ In order for a paradox of democratic education to arise the addition of two new ingredients were still required, and St. Louis provided for both: a concern for the (positive) freedom of individual citizens that went beyond Hegel's concerns on the one hand, and a focus on the creation of new educational institutions along the frontier on the other hand. Goldstein rightly notes that Hegel's Philosophy of Right integrates two paradoxical ideals in education. However, we only find a focus on self-reliance, self-trust, and democracy - the idea that citizens participate in the determination of their own institutions - once Hegelian thought reached America and encountered Transcendentalism, and once attempts were made to build educational institutions in a Hegelian spirit, which acknowledges the paradoxical character of the enterprise of educating citizens to be free.

There are two reasons why the paradox of education needed to reach American shores to become a democratic one-one concerning the history of ideas in the United States, the other its history as a country. First, the particular fusion of Hegelianism and Transcendentalism found in the intellectual climate in St. Louis around the Civil War produced a whole new kind of tension: namely one between (Emersonian) self-reliance and self-trust and freedom on the one hand, and government and educational institutions on the other. The St. Louis Hegelians were focused upon promoting freedom ("self-activity") and self-reliance of the individual, while at the same time sharing the Hegelian conviction that true ("positive") freedom is only possible within the institutions of the state. They thought that education would give "man the possession of the instrumentalities of intelligence" required to be a productive citizen. ${ }^{15}$ Education would help individuals 
fully participate in the state's institutions, and hence render them free.

Second, the St. Louis Hegelians' democratic reading of Hegel's philosophy of education was also driven by practical considerations, namely by the task of building new institutions, particularly educational institutions, along the American frontier. The most important thing that a "Hegelian ethic of self-actualization of the human spirit" required was an appropriate public schooling system. ${ }^{16}$ If the new nation was to have productive citizens, it would need to educate individuals into a "productive citizenship in a democratic society." 17 While the radical abolitionists held that man is "free and equal in the absence of social restraints," the St. Louis Hegelians objected that such a purely "negative or abstract theory of freedom" was far too one-sided and "suffered from a deficient understanding of the relationship of the individual to society." ${ }^{18}$ Drawing on Hegel's analysis of the French Revolution and the Reign of Terror, the St. Louis Hegelians saw a similar threat of disintegrative individualism, particularly along the American frontier, and particularly in the radical abolitionists' attitude towards the Union. The mere destruction of slavery would not be sufficient for the full emancipation of slaves. That requires positive freedom as well, which can only arise within the constraints of communities and their institutions. ${ }^{19}$ The "adamant individualism" of the pre-war period thus needed to be tempered by the promotion of the "gradual reform of social institutions," chiefly educational institutions. ${ }^{20}$ Brokmeyer, Harris, and Snider believed that the experience of the Civil War had prepared the young nation for such a new "era of social solidarity." 21

\section{HARRIS AND DEWEY ON EDUCATION}

For both Dewey and the St. Louis Hegelians, education plays a critical social role in inculcating democratic habits and ideals. Both recognized the fragility of democratic institutions and the importance 
of promoting a common faith in democratic values. Rather than being ordained and sustained by some absolute, supernatural power, such a faith had to come about through cooperative human work, especially in education. Still, in "Rival Readings of Hegel at the fin de siècle," Johnston argues that there were serious differences in pedagogical theory between Harris and Dewey. For example, Johnston points out that Dewey takes Harris to task for insufficiently appreciating that learning occurs when a situation that is at first perceived in only a problematically vague way becomes, through conceptual elaboration, perceived in a more precisely articulated way. In turn, he further suggests that these differences reflect distinct understandings of Hegel himself:

What we have when we juxtapose Harris and Dewey is not a Hegelian philosophy and psychology of education (Harris) pitted against a pragmatist, evolutionary, or instrumental one (Dewey); it is a metaphysical and transcendental/supernatural reading of Hegel against a non-metaphysical, naturalist, and immanent one. $^{22}$

We don't think this assessment accurately characterizes Harris, and that Johnston construes Harris's notions of the Absolute and the workings of Spirit in a manner that is much more in line with neo-theological readings of Hegel. Those readings, such as that espoused by T.H. Green or F.H. Bradley, were dominate in Dewey's time in academic circles (chiefly in the UK). However, Dewey rightly stressed that Harris and the St. Louis Hegelians were coming to Hegel from a much more secular orientation: that of the public schools. In any event, given how much Dewey drew upon Harris (and his translation and interpretation of Rosenkranz) for his Hegel lectures, we don't 
think that Dewey himself would attribute such an overtly theological understanding of Hegel to Harris. ${ }^{23}$

To be sure, Dewey and Harris had their disagreements on pedagogical issues. Harris elevated the function of spiritual institutions (such as that of the church and university), whereas Dewey was suspicious of such distinctions and emphasized the spiritual in all of our activity. Harris also championed classical studies and literature (Greek and Latin), not only as a means of freeing students from a parochialism born of knowing only a single language and participating in a single culture, but also as a "solvent word" for individuals to see their place in the arc of world history. ${ }^{24}$ Dewey worried that such subjects were so detached from their original context that they were apt to appear too lifeless and alien for capturing the interest of contemporary learners. In turn, Harris (and Susan Blow) thought that Dewey placed too much emphasis upon the socialization of the child to the world of work in early education.

Nevertheless, we think that their commonalities far outweigh their differences. In addition to their shared belief that a primary aim of education in America is to instill faith in democracy, they both decried Herbert Spencer's attitude of prioritizing science over other, particularly humanistic subjects. ${ }^{25}$ While Dewey also followed Harris and the St. Louis Hegelians in adopting a broadly anti-empiricistic view of knowledge and learning. The mind is not a blank slate, and knowing is not to be understood as mere receptivity. Learning is making, and knowledge is created. Thus, there is an emphasis in the educational theories of the Hegelians and Dewey alike on self-expression and activity: artmaking, game-playing, enacting and telling stories. Much of this activity — singing, dancing, playing games — is at the same time deliberately social. ${ }^{26}$ Through such activity, children confront others-other 
objects, other organisms, other selves, and eventually other ways of life and cultures - and come to see enlarged versions of themselves when they return to themselves from such imaginative endeavors.

Although education begins at home in the family, Hegel and his American followers stressed that it shouldn't remain there. At some point, education has to be moved outside of a family so that students can encounter others not tied to them by natural bonds of kinship and mutual affection. Hegel viewed schools as places where students begin this necessary transition from family to civic society, stressing the importance of rational thought and articulation in becoming a part of society. ${ }^{27}$ Hegel's thoughts on teaching center around his conception of Bildung - the process through which individuals are emancipated from their natural inclinations and become rationalized. ${ }^{28}$ Through the acquisition of "second nature," individuals become capable of ethical action, and not just ruled by their passions. As Snider colorfully puts it, "the World-Spirit is the chief pedagogue in the World-School." 29 Teachers serve as its avatars as they shepherd students into the spirit of their age.

\section{INSTITUTIONAL EDUCATION}

Through their institutionalization of American education, the St. Louis Hegelians gave Hegel's abstract educational philosophy its most concrete form. The institutionalization of Hegelian educational theory is most evident in its embodiment in the familiar division between primary, secondary, and higher forms of education and their attendant curricula, which stem from Harris's work on the Committees of Ten and Fifteen. Drawing upon Hegel and Rosenkranz, Harris had a stage-theory of the overall process for raising children to become good citizens. Following basic upbringing in the family (supplemented by the kindergarten), the elementary stage is an inventory that opens 
"the five windows of the soul" through arithmetic, geometry, reading and writing, grammar, and history. The secondary stage is more reflective, with curricula of inorganic and organic nature, literature, grammar and logic, history, mathematics, physics, Greek, Latin, Roman, and Hebrew. Finally, higher education is a comparative stage, where "each branch is studied in the light of all the others," with curricula of natural science, sociology, logic and mental philosophy, ethics and rhetoric, philosophy of history and literature, and comparative sciences. ${ }^{30}$ While Dewey was not so wed to such a set curriculum or succession of studies, he too embraced the idea of a progression of reflection aimed at the "the development of new attitudes towards, and new interests in, experience." ${ }^{\prime 3}$

For Harris, the education of a child requires a transition from "education by authority" to "education by insight." "S2 Such a replacement is necessary, because education by authority is inherently unstable. However, if education by insight is implemented too early:

there is this danger ... that the individual tends to become so self-conceited with what he considers knowledge gotten by his own personal thought and research, that he drifts towards empty agnosticism with the casting overboard of all authority. ... The problems of the reform movement centre, therefore, on the proper method of replacing this authoritative or passive method of education by education through self-activity. ${ }^{33}$

Striking such balance is a skill, requiring different methods and strategies at different stages of a child's development. Hence, we see why the St. Louis philosophers placed so much emphasis upon the 
education of educators. The issues they faced here were concrete. With heavy lobbying by Brackett, for instance, Harris was able to convince a reluctant school board to raise the standards of admission and graduation of the normal schools. ${ }^{34}$ They understood well that the social need to inform and train teachers in what is now called "best practices" demands its own set of institutions aimed at supporting, elevating, and professionalizing the teaching field. And their contributions to such institutions were legion. All were active in regional and national associations; Harris even served as president of the NEA. Snider, Davidson, and Blow established summer institutes and lecture series for teachers. Blow promoted and made accessible pedagogical materials for early childhood education (including Friedrich Fröebel's games). Harris edited a popular series of Appleton readers, as well as the book series in which Brackett's edition of Rosenkranz appeared. Brackett edited The Journal of Education. The list goes on. Again, Harris and his St. Louis colleagues found themselves implementing Hegelian principles of education in a most concrete fashion. Theirs was a model of how to follow Dewey's recommendation for recovering philosophy by applying it to the actual problems of the day. Paraphrasing Hegel's famous dictum from the preface of Philosophy of Right: their rational was very real, and their real was thoroughly rationalized.

This attention to education attains its reflective culmination in the academicization of education. By academicization, we mean not only the training of teachers, but the establishment of college and university units dedicated to the production of scholarship on teaching and learning, as well as the creation of outlets for the dissemination of such research. In "The Science of Education," Brackett called for an understanding of "pedagogics" as a science in its own right in the JSP, ${ }^{35}$ and Harris echoed this call in the preface he wrote for Rosenkranz's Philosophy of Education. ${ }^{36}$ Through such work, educators make 
their professions and self-activity their own objects of study. Thus, teaching becomes not an alien activity, but a self-conscious one, in the Hegelian sense. As they investigate and advocate for changes within their own activity, teachers see as well the workings of the world spirit in the transformations of their own practice.

Dewey also contributed much to the emergence of education as a field in its own right through his work with the Laboratory School in Chicago, and his later appointment to the Columbia Teachers College (by Harris's good friend and admirer, Nicholas Murray Butler). ${ }^{37}$ However, we wish to stress how the efforts on the part of folks like Harris to institute the academicization of education were what made it possible for someone like Dewey to have the kind of career that he did. So not only did the example of the St. Louis Hegelians give Dewey some hope for a career in philosophy, their efforts to elevate the study and practice of teaching also helped to make a place for someone like themselves - a champion of humanistic and democratic ideals thoroughly steeped in a tradition in Hegel-in higher education. As Dewey remarked, that type of career had not been available before.

\section{CONCLUSION}

By stressing how intertwined Dewey was with Harris and those within his orbit, we have made at least a preliminary case that Dewey's philosophy of education was not so much of a radical break from the Hegelianism that came before him. With its focus upon institutional development and reform, the particular brand of Hegelianism that took root outside the academy in the public schools of St. Louis put into concrete practice many of the ideas that Dewey would later give fuller philosophical expression. Much of the work Dewey is most revered for, including his abiding focus on establishing institutions to deal practically with problems of education and society, can thus be seen to 
be a just and fitting continuation of the efforts of his equally institutional and practically minded predecessors. Indeed, one might even argue that their efforts helped to make Dewey's work possible.

See Jim Garrison, “The 'Permanent Deposit' of Hegelian Thought in Dewey's Theory of Inquiry," Educational Theory 56, no. 1 (2006): 1-37; James A. Good, "John Dewey's 'Permanent Hegelian Deposit' and the Exigencies of War," Journal of the History of Philosophy 44, no. 2 (2006): 293-313; John R. Shook and James A. Good, eds., John Dewey's Philosophy of Spirit (With the 1897 Lecture on Hegel) (New York: Fordham University Press, 2010); James Scott Johnston, "Rival Readings of Hegel at the fin de siecle: The Case of William Torrey Harris and John Dewey," History of Education 42, no. 4 (2013): 423-443.

2 Johnston, "Rival Readings," 443.

3 John Dewey, "From Absolutism to Experimentalism," in The Later Works, 1925-1953, ed. Jo Ann Boydston (Carbondale: University of Southern Illinois Press, 1981-91), 154.

4 Morris translated Rosenkranz's "Hegel as Publicist" for the JSP in 1872, and Dewey offered to translate Rosenkranz's introduction to Hegel's Encyclopedia.

5 The significant contributions of Anna Brackett and other women in the St. Louis movement (such as Susan Blow, mentioned below) deserve their own lengthy treatment. Fortunately, Dorothy G. Rogers, America's First Women Philosophers: Transplanting Hegel, 1860-1925 (London: Continuum, 2005), 74, gives us precisely what is called for. Among other things, one can see from Rogers's study how the St. Louis Hegelians, even many of the men, had pleasantly moved well beyond Hegel in their views of the intellectual capacities of women and the roles that they may play in civil society.

6 One wistfully imagines what might happen if someone of such intellectual breadth and institutional experience were again to be appointed as secretary of education. 
7 Dewey, "From Absolutism," 154.

8 Joshua D. Goldstein, "Hegel and the Paradox of Democratic Education," The European

Legacy 18, no. 3 (2013): 308-26; Ibid., 309.

9 Goldstein, "Hegel and the Paradox,” 314.

10 Goldstein, 309.

11 Goldstein, 314.

12 Goldstein, 311.

13 Goldstein, 309.

14 As put by Denton Jacques Snider, “America, The Superior Hegelian State," in The American Hegelians: An Intellectual Episode in the History of Western America, ed. William H. Goetzmann (New York: Alfred A. Knopf, Inc., 1973), 189.

15 Harris remarks, "Spencer calls education the subject which involves all other subjects, and the one in which they should all culminate. But someone has better said that school education is the giving to man the possession of the instrumentalities of intelligence.” William Torrey Harris, “Lecture V. - February 4th, 1893. Herbert Spencer and What Knowledge is of Most Worth," in The Philosophy of Education: Harris, William Torrey, 1835-1909 (Miami, Florida: HardPress Publishing, 1893), 8.

16 James A. Good, “A 'World-Historical Idea': The St. Louis Hegelians and the Civil War," Journal of American Studies 34, no. 3 (2000): 447.

17 Good, “A 'World-Historical Idea,” 448.

18 Good, 451.

19 Good, 451.

20 Good, 448.

21 Good, 461.

22 Johnston, "Rival Readings," 424-25.

23 See also Good, "John Dewey's," 299ff. If we are right, then the (largely An- 
glo) tradition of secularizing Hegel originates not with Dewey, but rather with the St. Louis Hegelians.

24 William Torrey Harris, "Preface," Journal of Speculative Philosophy 1 (1867); J. J. Chambliss, "William Torrey Harris' Philosophy of Education,” Paedagogica Historica 5, no. 2 (1965): 326.

25 Compare Harris, "Lecture V.," 7-9, with Article III of John Dewey, "My Pedagogic Creed," in The American Hegelians: An Intellectual Episode in the History of Western America, ed. William H. Goetzmann (New York: Alfred A. Knopf, Inc., 1973), 317-318. In that lecture, Harris goes so far as to say that " $[\mathrm{t}]$ here was never a more unscientific book than Spencer's essay on education; for while he praises science, he does not apply it to education as it is and has been."

26 One can see a great commonality between Hegel's abstract theory of education with the pedagogical practices advocated by Fröebel, the founder of the kindergarten movement. Although contemporaries in time and overlapping in place (and despite having some acquaintances in common), it is unclear whether Hegel and Fröebel were directly aware of one another's work. In any event, Rogers's, America's First Women Philosophers, makes clear that at least one St. Louis Hegelian, Susan Blow, explicitly brought the thoughts of them both together in concrete practice. Indeed, it is also interesting that while the kindergarten movement was put down in Prussia as being potentially subversive, it eventually took root and flourished in America.

27 Allen W. Wood, "Hegel on Education," in Philosophy as Education, ed. Amélie O. Rorty (London: Routledge, 1998), 1-30.

28 Terry Pinkard, German Philosophy 1760-1860: The Legacy of Idealism (Cambridge, Massachusetts: Cambridge University Press, 2008), cited in Ari Kivela, "Toward a Modern Concept of Schooling: A Case Study on Hegel," Educational Philosophy and Theory 50, no. 1 (2018): 72-82.

29 Denton Jacques Snider, "The Public School and the Universal School," in The American Hegelians: An Intellectual Episode in the History of Western America, ed. William H. Goetzmann (New York: Alfred A. Knopf, Inc., 1973), 274.

30 Harris, "Lecture V.," 8-9. 
31 Dewey, "My Pedagogic," 316.

32 Dewey drew a related distinction between education by effort and interest in John Dewey's, "Interest in Relation to Training of the Will," in Second Supplement to the Herbart Year Book for 1895, ed. Charles A. McMurry (Bloomington, Illinois: Pantagraph Printing and Stationary Company, 1896), 209-246 (an 1896 address to the Herbart Society at which Harris was present).

33 William Torrey Harris, "Lecture II. - Saturday, January 14th, 1893. Problems Peculiar to American Education," in The Philosophy of Education: Harris, William Torrey, 1835-1909 (Miami, Florida: HardPress Publishing, 1893), 3-4. Harris's criticism of education by authority bears a striking resemblance to Peirce's criticism of the method of authority in "The Fixation of Belief” (CP 5.380).

34 Rogers, America's First Women Philosophers, 74.

35 Anna C. Brackett, “The Science of Education," Journal of Speculative Pbilosophy 12 (1878): 67-81.

36 Chambliss, "William Torrey Harris'," 326.

37 Kurt F. Leidecker, Yankee Teacher: The Life of William Torrey Harris (New York: The Philosophical Library, 1946), 513ff. Butler's esteem of Harris is evidenced by the following: "I Measure my words when I say that in my judgment Dr. Harris had the one truly great philosophical mind which has yet appeared on the western continent." 